\title{
TRAINING AND JOB SATISFACTION FOR ORGANIZATIONAL EFFECTIVENESS: A CASE STUDY FROM THE BANKING SECTOR
}

\author{
Rahman, $\mathbf{H}$.
}

Every organization needs well-adjusted, trained, and experienced people to perform its activities effectively and efficiently. Today's business environment has become complex; the training for employees' education is becoming a diver for adjusting dynamic change in organizational interfaces. This survey reveals that employee training and job satisfactions have a significant positive relationship with organizational effectiveness. The survey also indicates that job dissatisfaction has an insignificant relationship with organizational effectiveness in commercial banks. The study indicates that to chase dynamic business environments, management should focus on building human resources through diverse training for promoting organizational effectiveness.

JEL Classification: M10, M12

Keywords: Training; job satisfaction; job dissatisfaction; organizational effectiveness; employees; commercial bank.

\section{Introduction}

Every business is a people business. At the heart of every successful business are the people who make things happen. Human capital is its most valuable resource, which provides the solid foundation needed to build long-term profitability and ongoing success of an organization. Human capital consists of the "people assets" that drive an organization's continuous development and sustained growth, and includes the collective attitudes, skills, abilities, and knowledge base of an entire workforce. A firm's human capital can also provide a unique source of competitive advantage that is difficult for its competitors to replicate (Hasebur Rahman, M., and Abdullah Al Mamun, M., 2013). Human resource management plays an important role in an organization's ability to remain competitive (Klienman, 2000). Continuously working for the development and nourishment of the workforce increases its role in the betterment of the work environment of any organization. Owing to this, most of the managers around the world are creating and enhancing their roles in providing extensive training with the aim of achieving defined goals of the organization. It can not only lift the position of the employees but also the image of the organization to the outside world, (Lu, J.F., Tjosvold, D., and Kan Shi., 2010). This need for training pervades all levels of industry, from a national level where a country's wellbeing is enhanced by training, to each company where productivity is improved, down to the individual whose skills are enhanced and as a result improve their position in the workplace. Any organization that wants to succeed, and to continue to succeed, has to maintain a workforce consisting of people who are willing to learn and develop continuously. Training and developing human capital are tremendously important in the effective management and maintenance of a skilled workforce. Training is one of the ways of improving an organization's effectiveness (Alipour, M., Salehi, M,. and Shahnavaz, A., 2009).

Global competition, downsizing, reengineering, information technology, and total quality are posing challenges in business (Hasebur Rahman, M., 2013b). In order to compete in a global economy with rapid social and technological changes, skills and knowledge are becoming more and more important. These changes do also have far reaching implications for the work environment and the labor market. Companies, employees and employers are affected, so there are increasing demands for high-skilled employees and decreasing demand for less qualified labor (Rabe, M., and Giacomuzzi, S., 2012). Employee training is becoming a necessity for every organization in the current 
environment. Employees are entrusted with different roles and responsibilities in banks. Training enables them to carry out these roles and responsibilities efficiently and also learn new things, which will prepare them to take up higher responsibilities in the future (Karthikeyan, K., Karthi, R., and Graf, S., 2010).

With the growing of the economy in Bangladesh, a dramatic change has been taking place in the service sector. Both public and private commercial banks are operating in the country with highly competitive pressure in customized services (Hasebur Rahman, M., 2013a). Banking jobs are now considered one of the challenging and dynamic professions in Bangladesh. A large number employees serves banking customers at competitive pressure (Hasebur Rahman, M., 2013b). The role of banks is essentially carried out by people, and therefore it is essential to have a well-trained and motivated staff to manage the banking operations. The success of the banking operations depends upon the people, the employees and the effectiveness of the employees is very much dependent on the training input given to the employees (Karthikeyan, K., Karthi, R., and Graf, S., 2010). All the above-mentioned aspects impressed the researcher to study the effectiveness of training and job satisfaction for organizational effectiveness in public and private sector commercial banks in Bangladesh and come out with recommendations for the future.

\section{Research Objective}

The study has been conducted mainly to find out the Effectiveness of Training and Job Satisfaction for Organizational Effectiveness in public and private sector commercial banks in Bangladesh. However, the objective of this study can be divided into four major categories:

A. To investigate the respondents' demographics;

B. To investigate the effects of training and development on organizational effectiveness;

C. To investigate the effects of job satisfaction on organizational effectiveness; and

D. To investigate the effects of job dissatisfaction on organizational effectiveness.

\section{Literature Review and Hypothesis Development}

3.1 Training and Development for Organizational Effectiveness: Employee training is a learning experience: it seeks a relatively permanent change in employees that improves their job performance. Thus, training involves changing skills, knowledge, attitudes, or behavior (C. S. Duncan, J. D. Selby-Lucas, and
W. Swart, 2002). A training and development program is a planned education component and an exceptional method for sharing the culture of the organization; it goes beyond one's job skills to understanding workplace skills, developing leadership, innovative thinking and problem resolving (Meister, 1998). The successful and prosperous future of an organization is dependent on its skilled, knowledgeable and experienced workforce. That is why training is a fundamental and effectual instrument in successful accomplishment of the firm's goals and objectives. Training not only improves them resourcefully, but also gives them a chance to learn their job virtually and perform it more competently, hence increasing a firm's productivity (Nadeem, M., 2010). An employee training program can help increase productivity and quality of work life. Training acts as a caring guardian for the organization as well as for employees. It increases revenue and reduces staff turnover and absenteeism. Training is not a cost; it is the most sustainable investment of a company to improve the level of motivation of the employee leading to superior customer satisfaction and quality product and service (Karim, Huda and Khan, 2012).

On the basis of these research indications, it is concluded that there is a positive association between training and organizational effectiveness. Therefore, the first hypothesis $\left(\mathrm{H}_{1}\right)$ of the study is that there is a significant relationship between job satisfaction and organizational effectiveness.

\subsection{Job Satisfaction for Organizational Effectiveness:} Employees get a lot of benefits from the employee training and development program (Jehanzeb and Bashir, 2012). Most employees recognize the importance of a training program and would like to increase their salaries (Dillich, 2000). Employees have no feeling about their organizations, if they think that their organizations are not caring about them (Garger, 1999). Companies which are willing to spend money on their employees, give value to work with those companies, even though that investment eventually benefits the organization itself (Wilson, 2000). Companies which provide training and development programs for their employees are achieving a high level of employee satisfaction and low employee turnover (Wagner, 2000). Training increases an organization's reliability for the reason that employees recognize their organization is investing into their future careers (Rosenwald, 2000). Glance et al. (1997) posited that workforce training augments employee commitment with the organizations and motivating the employees to perk up their work performance. It is a proven fact that employees who are satisfied with their jobs attain 
a higher rate of success while performing their job than dissatisfied employees. Employee training remains one of the widely driven forces toward job satisfaction (Batool, A., and Batool, B., 2012).

On the basis of these literature reviews, it is concluded that there is a positive association between satisfaction and organizational effectiveness. Therefore, the second hypothesis $\left(\mathrm{H}_{2}\right)$ of the study is that there is a significant relationship between training and organizational effectiveness.

3.3 Job Dissatisfaction and Organizational Effectiveness: Job satisfaction is defined as revised treatment of job satisfaction. Employees become dissatisfied when they perceive that they have received inadequate financial benefits from a job, job insecurity, lack of autonomy at work, lack of career development in organization and other job related factors.

Therefore, this study is initiated to find out whether there is any association between job dissatisfaction and organizational effectiveness. Therefore, the third hypothesis $\left(\mathrm{H}_{3}\right)$ of the study is that there is a significant relationship between job dissatisfaction and organizational effectiveness.

\section{Materials and Methods}

This section defines the research design, population \& samples, data collection period, data collection procedures \& techniques and test of reliability of scale of data for examining organizational effectiveness in relation to training, job satisfaction and job dissatisfaction factors in commercial banks in Bangladesh. The said factors are training \& development, job satisfaction, job dissatisfaction and organizational effectiveness.

4.1 Research Design: This study is descriptive and hypotheses testing in nature. This study aimed to examine the factors that affect organizational effectiveness. This study involved hypothesis testing based on what has been found in the literature review. The hypothesis tested was explaining the relationship between the independent and dependent variables. Finally, data was collected using the survey method where questionnaires were used to collect information.

4.2 Population and Sample: For the questionnaire survey, a convenient method of sampling was used. There is no available source of commercial banking officers. Therefore, friends, relatives, and other informal reference group were used to locate the potential respondents in Bangladesh. Questionnaires were sent by email and postal mail, and directed to 200 respondents. The number of initial replies received was 115 .
After screening the first round of replies, there were 115 respondents; a second round questionnaire survey was conducted by the researcher, and finally 140 respondents were selected for this study.

4.3 Data Collection Technique: This study is mainly based on primary data originating from the survey. For this purpose, a constructed questionnaire was developed. Questions regarding demographic characteristics of the respondents and issues related to training / development, job satisfaction, job dissatisfaction and organizational effectiveness were constructed, measured and investigated through a 5 point scale standardized by BrayfieldRothe (1951). The scale consists of 20 statements; each statement has five options/ points such as, strongly agree/ 5, agree/ 4, undecided/3, disagree/ 2, and strongly disagree/ 1.

4.4 Data Analysis Technique and Reliability of Scale: The SPSS statistical software package was used for statistical analysis. Reliability of data was measured using Cronbach's Alpha test. Chronbach Alpha (Chronbach, 1951) is 0.559. The Alpha value is higher than that suggested by Nunnally (1978) and therefore data collected can be considered reliable.

Table 1 Reliability statistics

\begin{tabular}{|l|c|c|}
\hline Factor & Cronbach's Alpha & N of Items \\
\hline Training & 0.495 & 5 \\
\hline Job Satisfaction & 0.517 & 5 \\
\hline Job Dissatisfaction & 0.420 & 5 \\
\hline $\begin{array}{l}\text { Organizational } \\
\text { Effectiveness }\end{array}$ & 0.319 & 5 \\
\hline Average & 0.559 & 20 \\
\hline
\end{tabular}

Descriptive statistical techniques such as mean and standard deviation were used to measure the mean scores and their variability. Pearson Correlation is used to indicate correlations among the variables, Linear Regression analysis is used to test the hypothesis.

\section{Analysis and Findings}

\subsection{Respondents' Demographics:}

Questionnaires were distributed to the employees of commercial banks; among them 50\% are public and 50\% are private commercial banks. Frequencies of employees as per designation comprise $7.1 \%$ junior officers, $37.1 \%$ officers, $43.6 \%$ senior officers, $3.6 \%$ principal officer and $8.6 \%$ senior principal officer. $48.6 \%$ of respondents hold a monthly salary below Tk $30,000,37.1 \%$ of the respondents have a salary between Tk 30,000-50,000 
and $14.4 \%$ have a monthly salary of $\operatorname{Tk} 50,000.25 .7 \%$ of the respondents have an age younger than 30 years, $55 \%$ of respondents are aged between 30-45 years and $19.3 \%$ are over 45 years old. $72.9 \%$ of the respondents have work experience of less than 10 years, $10 \%$ of the respondents have between 10-20 years of work experience and $17.1 \%$ of the respondents have more than 20 years of employment experience. The sample is made up of $92.1 \%$ males and $7.9 \%$ females; $77.9 \%$ are married and $22.1 \%$ are single. In addition, $2.1 \%$ have an HSC, $17.1 \%$ hold a bachelor's degree and $80.7 \%$ hold a master's level.

Table 2 Respondents 'demographics

\begin{tabular}{|c|c|c|c|}
\hline & & Frequency & Percent \\
\hline \multirow[t]{3}{*}{ Bank } & Public Commercial & 70 & 50.0 \\
\hline & Private Commercial & 70 & 50.0 \\
\hline & Total & 140 & 100.0 \\
\hline \multirow{6}{*}{$\begin{array}{l}\text { Designation } \\
\text { (Equivalent) }\end{array}$} & Junior Officer & 10 & 7.1 \\
\hline & Officer & 52 & 37.1 \\
\hline & Senior Officer & 61 & 43.6 \\
\hline & Principal Officer & 5 & 3.6 \\
\hline & $\begin{array}{l}\text { Senior Principal } \\
\text { Officer }\end{array}$ & 12 & 8.6 \\
\hline & Total & 140 & 100.0 \\
\hline \multirow{4}{*}{$\begin{array}{l}\text { Salary } \\
\text { (Gross) }\end{array}$} & Below Tk 30,000 & 68 & 48.6 \\
\hline & Tk 30,000-50,000 & 52 & 37.1 \\
\hline & Above Tk 50,000 & 20 & 14.3 \\
\hline & Total & 140 & 100.0 \\
\hline \multirow[t]{4}{*}{ Age } & Below 30 years & 36 & 25.7 \\
\hline & 30-45 year & 77 & 55.0 \\
\hline & Above 45 years & 27 & 19.3 \\
\hline & Total & 140 & 100.0 \\
\hline \multirow{4}{*}{$\begin{array}{l}\text { Work } \\
\text { Experience }\end{array}$} & Below 10 years & 102 & 72.9 \\
\hline & 10-20 year & 14 & 10.0 \\
\hline & Above 20 years & 24 & 17.1 \\
\hline & Total & 140 & 100.0 \\
\hline \multirow[t]{3}{*}{ Gender } & Male & 129 & 92.1 \\
\hline & Female & 11 & 7.9 \\
\hline & Total & 140 & 100.0 \\
\hline \multirow{3}{*}{$\begin{array}{l}\text { Marital } \\
\text { Status }\end{array}$} & Married & 109 & 77.9 \\
\hline & Unmarried & 31 & 22.1 \\
\hline & Total & 140 & 100.0 \\
\hline \multirow[t]{4}{*}{ Education } & HSC & 3 & 2.1 \\
\hline & Bachelor & 24 & 17.1 \\
\hline & Master & 113 & 80.7 \\
\hline & Total & 140 & 100.0 \\
\hline
\end{tabular}

Source: Field Survey, 2013.
5.2 Descriptive Statistics: Descriptive statistics such as mean (5-point scale) and standard deviation (Higher indicates higher variability of customers perceptions) were used to measure the variables and also used to describe the mean of the dependent and independent variables.

\section{Table 3 Descriptive statistics}

\begin{tabular}{|l|c|c|c|}
\hline Variables & $\overline{\boldsymbol{X}}$ & $\boldsymbol{\sigma}$ & $\mathbf{N}$ \\
\hline Training and Development & 4.3729 & 0.31482 & 140 \\
\hline Job Satisfaction & 3.9471 & 0.35471 & 140 \\
\hline Job Dissatisfaction & 2.8000 & 0.45959 & 140 \\
\hline Organizational Effectiveness & 4.0729 & 0.30929 & 140 \\
\hline
\end{tabular}

Table 3 shows that the mean value of training and development is 4.3729 (high) and standard deviation is 0.31482 (low variability). The mean value of job satisfaction is 3.9471 (moderate high) and standard deviation is 0.35471 (low variability). The mean value of job dissatisfaction is 2.8000 (moderate) and standard deviation is 0.45959 (low variability). Finally, the mean value of organizational effectiveness is 4.0729 (high), the standard deviation 0.30929 (low variability).

5.3 Correlations among Variables: Bivariate Correlations are used to know the nature, direction and significance of the bivariate relationship of the variables of this study. Therefore, the researcher used the Bivariate Correlations procedure to compute Pearson's correlation coefficient.

Table 4 shows the Pearson's correlation coefficient of the variables of the study. Based on the analysis presented in Table 4, the results show that there is a positive correlation between the variables; the correlation between job satisfaction and training/ development indicates that there was a positive correlation between two variables with coefficient correlation $r=.010$ at $p<.904$ level. In addition, there is a positive significant correlation between the variables; the correlation between training $\&$ development and job dissatisfaction indicates that there was a significant correlation between two variables with coefficient correlation $r=.207$ at $p<0.014$ level. In addition, there was a significant positive correlation between training \& development and organizational effectiveness, $\mathrm{r}=.440$ at $p<0.00$ level. The correlation between job satisfaction and job dissatisfaction indicates that there was a negative significant correlation between two variables with coefficient correlation $r=-.229$ at $p<.006$ level. In addition, there is a positive correlation between the variables; the correlation between job 
Table 4 Correlations among variables

\begin{tabular}{|c|c|c|c|c|c|}
\hline & & $\begin{array}{c}\text { Training } \\
\text { \& Development }\end{array}$ & $\begin{array}{c}\text { Job } \\
\text { Satisfaction }\end{array}$ & $\begin{array}{c}\text { Job } \\
\text { Dissatisfaction }\end{array}$ & $\begin{array}{l}\text { Organizational } \\
\text { Effectiveness }\end{array}$ \\
\hline \multirow{3}{*}{$\begin{array}{l}\text { Training } \\
\text { \& Development }\end{array}$} & Pearson Correlation & 1 & & & \\
\hline & Sig. (2-tailed) & & & & \\
\hline & $\mathrm{N}$ & 140 & & & \\
\hline \multirow{3}{*}{$\begin{array}{l}\text { Job } \\
\text { Satisfaction }\end{array}$} & Pearson Correlation & .010 & 1 & & \\
\hline & Sig. (2-tailed) & .904 & & & \\
\hline & $\mathrm{N}$ & 140 & 140 & & \\
\hline \multirow{3}{*}{$\begin{array}{l}\text { Job } \\
\text { Dissatisfaction }\end{array}$} & Pearson Correlation & $.207^{\star}$ & $-.229^{\star *}$ & 1 & \\
\hline & Sig. (2-tailed) & .014 & .006 & & \\
\hline & $\mathrm{N}$ & 140 & 140 & 140 & \\
\hline \multirow{3}{*}{$\begin{array}{l}\text { Organizational } \\
\text { Effectiveness }\end{array}$} & Pearson Correlation & $.440^{\star *}$ & $.712^{\star *}$ & -.091 & 1 \\
\hline & Sig. (2-tailed) & .000 & .000 & .284 & \\
\hline & $\mathrm{N}$ & 140 & 140 & 140 & 140 \\
\hline
\end{tabular}

* Correlation is significant at the 0.05 level (2-tailed).

${ }^{* *}$ Correlation is significant at the 0.01 level (2-tailed).

satisfaction and organizational effectiveness indicates that there was a positive significant correlation between two variables with coefficient correlation $r=.712$ at $p<0.00$ level. Finally, there was a negative correlation between job dissatisfaction and organizational effectiveness, $\mathrm{r}=-.091$ at $p<0.284$ level.

5.4. Regression Analysis: In order to achieve the objective of this study, multiple regressions were used to study the effect of the independent variables $\left(\mathrm{X}_{1}=\right.$ Training \& Development, $\mathrm{X}_{2}=$ Job Satisfaction, $\mathrm{X}_{3}=$ Job Dissatisfaction) to dependent variable ( $Y=$ Organizational Effectiveness). The significance level for perceived quality, perceived value, customer expectation and corporate image are accepted on Alpha $(\alpha)=1 \%$, significance level $=99 \%$ significant at $1 \%(*)$. Table 5 shows the analysis of multiple regressions. The value of $\mathrm{R}$ was (.834), the value of $\mathrm{R}$ square was (.695) and the standard error of the estimate was (.17274). The model summary and the data are shown in Table 5.

Table 5 Model summary

\begin{tabular}{|l|c|c|c|c|}
\hline Model & R & R Square & $\begin{array}{c}\text { Adjusted R } \\
\text { Square }\end{array}$ & $\begin{array}{c}\text { Std. Error of } \\
\text { the Estimate }\end{array}$ \\
\hline $\mathbf{1}$ & $.834 \mathrm{a}$ & .695 & .688 & .17274 \\
\hline
\end{tabular}

a. Predictors: (Constant), Job Dissatisfaction, Training \& Development, Job Satisfaction

The results from Table 5 show that the regression equation explains more than $69.5 \%$ of the variability in organizational effectiveness. This is an acceptable level for $\mathrm{R}^{2}$ ( $\mathrm{R}$ Square) in explaining variability of organizational effectiveness. The results of the multiple regression models indicate that job satisfaction, training \& development, job dissatisfaction explain the variance in organizational effectiveness. The value of $\mathrm{R}^{2}$ ( $\mathrm{R}$ Square) is an acceptable value for explaining variability of organizational effectiveness. Analysis of variance test statistics (ANOVA) indicates that the model is significant at $\alpha=0.000$. Table 6 provides information on the significance of the model indicating a significant $p$-value of 0.000. The ANOVA findings are shown in Table 6 below.

\section{Table 6 ANOVA}

\begin{tabular}{|l|l|r|r|r|r|r|}
\hline \multicolumn{2}{|l|}{ Model } & $\begin{array}{c}\text { Sum of } \\
\text { Squares }\end{array}$ & df & $\begin{array}{c}\text { Mean } \\
\text { Square }\end{array}$ & F & Sig. \\
\hline \multirow{2}{*}{1} & Regression & 9.239 & 3 & 3.080 & 103.204 & $.000 \mathrm{a}$ \\
\cline { 2 - 7 } & Residual & 4.058 & 136 & .030 & & \\
\cline { 2 - 7 } & Total & 13.297 & 139 & & & \\
\hline
\end{tabular}

a. Predictors: (Constant), Job Dissatisfaction, Training \& Development, Job Satisfaction

b. Dependent Variable: Organizational Effectiveness

Table 6 shows the ANOVA findings that the independent variables as a whole have significant relationships with customer satisfaction $(\mathrm{F}=103.204)$ (Sig 0.000). Table 7 shows that all the values of the T-statistic are significant for training and development and job satisfaction and insignificant for job dissatisfaction. Thus, all the independent variables can be retained in the model. In other words, these variables can explain the change in 
Table 7 Coefficients ${ }^{a}$

\begin{tabular}{|c|c|c|c|c|c|c|c|c|}
\hline \multirow{2}{*}{\multicolumn{2}{|c|}{ Model }} & \multicolumn{2}{|c|}{$\begin{array}{c}\text { Unstandardized } \\
\text { Coefficients }\end{array}$} & \multirow{3}{*}{$\begin{array}{c}\begin{array}{c}\text { Standardized } \\
\text { Coefficients }\end{array} \\
\text { Beta }\end{array}$} & \multirow{3}{*}{$\begin{array}{c}\mathbf{t} \\
-.678 \\
\end{array}$} & \multirow{3}{*}{$\begin{array}{l}\text { Sig. } \\
.499 \\
\end{array}$} & \multirow{2}{*}{\multicolumn{2}{|c|}{$\begin{array}{l}\text { Collinearity } \\
\text { Statistics }\end{array}$}} \\
\hline & & \multirow{2}{*}{$\begin{array}{c}\text { B } \\
-.186\end{array}$} & \multirow{2}{*}{$\begin{array}{c}\text { Std. Error } \\
.275\end{array}$} & & & & & \\
\hline 1 & (Constant) & & & & & & Tolerance & VIF \\
\hline & Training and development & .429 & .048 & .437 & 9.011 & .000 & .954 & 1.049 \\
\hline & Job Satisfaction & .613 & .043 & .703 & 14.417 & .000 & .944 & 1.059 \\
\hline & Job Dissatisfaction & -.014 & .034 & -.020 & -.405 & .686 & .904 & 1.107 \\
\hline
\end{tabular}

a. Dependent Variable: Organizational Effectiveness

organizational effectiveness. Table 7 shows that two independent variables were found to be very significant and supportive of the hypothesis regression analysis except job satisfaction was not statistically significant and it support the alternative hypothesis.

\section{Table 8 The summary of hypotheses results}

\begin{tabular}{|l|c|}
\hline Hypotheses & Results \\
\hline $\begin{array}{l}\text { H1: There is a significant relationship } \\
\text { between training \& Development and } \\
\text { organizational effectiveness. }\end{array}$ & Accepted \\
\hline $\begin{array}{l}\text { H2: There is a significant relationship } \\
\text { between job satisfaction and organizational } \\
\text { effectiveness. }\end{array}$ & Accepted \\
\hline $\begin{array}{l}\text { H3: There is a significant relationship } \\
\text { between job dissatisfaction and } \\
\text { organizational effectiveness. }\end{array}$ & Rejected \\
\hline
\end{tabular}

Multiple regression analysis in Table 7 was employed to determine whether training and development have an effect on organizational effectiveness; the result of regression analysis revealed that there is a significant relationship between training and development and organizational effectiveness $(p=0.00) ; \mathrm{B}=0$. 429. The hypothesis is accepted because the result of significance is less than 0.05 (Significance requirement standard $<0.05)$. Therefore, the first $\left(\mathrm{H}_{1}\right)$ hypothesis is accepted. Regression analysis, as in Table 7, was employed to determine whether job satisfaction has an effect on organizational effectiveness; the result of regression analysis revealed that there is a significant relationship between these two variables at the significance level $p=0.00 \mathrm{~B}=.613$. The hypothesis is accepted because the result of significance is less than 0.05 (Significance requirement standard $<0.05)$. Therefore, the second hypothesis $\left(\mathrm{H}_{2}\right)$ is accepted. In contrast, the multiple regression analysis (table 7) was employed to determine whether job dissatisfaction has an effect on organizational effectiveness; the result of the regression analysis revealed that there was no significant relationship between job dissatis-faction and organizational effectiveness $(P=.686) ; \mathrm{B}=-0.014$. Because the significant value can't be met, the requirement which is the value of significant should be less than 0.05 . Therefore, the third alternative hypothesis $\left(\mathrm{H}_{3}\right)$ is rejected.

\section{Conclusion and Recommendation}

In order to achieve economic excellence and organizational effectiveness in commercial banks, an efficient crop of officers is indispensable. An efficient and effective banker can deliver service to the customer in an efficient manner. Therefore, an effective training and development program should be integrated in human resource management practices for organizational effectiveness in commercial banks in Bangladesh. The work brings out that training and job satisfaction are positively linked to organizational effectiveness. Job dissatisfaction among employees hinders organizational effectiveness of commercial bank in Bangladesh. Competent employees don't remain competent forever. Skills deteriorate and become obsolete and new skills need to be learned (Stephen P. Robbins et al., 2009). A training and development program can foster learning new techniques and methods to perform jobs with the fullest efficiency and effectiveness. A successful training and development program assists the strategic requirements of the organization and also satisfies the individual needs of the people working on it. Effective training programs also help employees to concentrate on their individual career development, which ultimately assists in achieving both organizational short- and long-term objectives.

The study's findings show that training \& development and job satisfaction are the most important components of organizational effectiveness in commercial banks. A training and development program should be a core tool of human resource practices in commercial banks in order to have satisfied, loyal, and efficient employees in commercial banking operations. 


\section{References}

Alipour, M., Salehi, M., Shahnavaz, A. (2009). A Study of on the Job Training Effectiveness: Empirical Evidence of Iran. International Journal of Business and Management, 4(11): 63-68

Batool, A., Batool, B. (2012). Effects of employees training on the organizational competitive advantage: Empirical study of Private Sector of Islamabad, Pakistan. Far East Journal of Psychology and Business, 6(1): 59-72.

Duncan, C. S., Selby-Lucas, J. D., Swart, W. (2002). Linking Organizational Goals and Objectives to Employee Performance: A Quantities Perspective. Journal of American Academy of Business, 314-318.

Dillich, S. (2000). Corporate universities. Computing Canada, 26 (16): 25

Garger, E. M. (1999). Goodbye training, hello learning. Workforce, 78 (11): 35-42.

Hasebur Rahman M. (2013b). Employees' Motivation in Public and Private Commercial Banks in Bangladesh: A Study on Need-Based Approach. Global Disclosure of Economics and Business, 2(2): 91.

Hasebur Rahman, M. (2013). Job Stress- Employees Performance and Health: A Study on Commercial Bank in Bangladesh. Global Journal of Management and Business Research, 13(4).

Hasebur Rahman, M., Abdullah Al Mamun, M. (2013). HRM Focus on Distinctive Human Capital and Strategy of Building-Retaining Competitive Advantage. Global Journal of Management and Business Research, 13(11): 13-18.

Jehanzeb, K., Bashir, N. A. (2012). Training And Development Program and Its Benefits to Employees and Organizations: A Conceptual Study. Far East Journal of Psychology and Business, 9(2): 58-71.

Karim, M. R., Huda, K. N., Khan, R. S. (2012). Significance of Training and Post Training Evaluation for Employee Effectiveness: An Empirical Study on Sainsbury's Supermarket Ltd, UK. International Journal of Business and Management, 7(18): 141-148.

Karthikeyan, K., Karthi, R., Graf, S. (2010). Impact of Training in Indian Banking Sector - An Empirical
Investigation. International Journal of Business and Management, 5(7): 77-83.

Kleiman L.S. (2000). Human Resource Management: A Managerial Tool for Competitive Advantage, 2nd Edn.,South-Western College Publishing, Cincinnati, OH.

Lu, J.F., Tjosvold, D., Shi, K.. (2010). Team Training in China: Testing and Applying the Theory of Cooperation and Competition, Journal of Applied Social Psychology, 40(1): 101-134.

Meister, J. C. (1998). Ten steps to creating a corporate university. Training and Development, 52(11): 38-43.

Nadeem, M. (2010). Role of Training in Determining the Employee Corporate Behavior with Respect to Organizational Productivity: Developing and Proposing a Conceptual Model. International Journal of Business and Management,5(12): 206-211.

Glance, N. S., Hogg, T., Huberman, B. A. (1997). Training and Turnover in the Evolution of Organizations, Organization Science, 8: 84.

Rabe, M.,Giacomuzzi, S. (2012).Effect of Training Courses on Coping Strategies. Advances in Business-Related Scientific Research Journal, 3(2): 135-146.

Rosenwald, M. (2000). Working class: More companies are creating corporate universities to help employees sharpen skills and learn new ones. Boston Globe, $\mathrm{H} 1$.

Robbins, S. P. et al. (2009). Organizational Behavior. India:Pearson Prentice Hall.

Wagner, S. (2000). Retention: Finders, keepers. Training and Development, 54(8): 64.

Wilson, C. (2000). More companies recognize the impact of learning centers. St. Louis Post-Dispatch, C8.

Author

Md. Hasebur Rahman Assistant Professor

Department of Business Administration Pabna University of Science and Technology Pabna-6600, Bangladesh hasebur7208@yahoo.com 


\section{Appendix:}

\section{Questionnaire}

Training and Job Satisfaction for Organizational Effectiveness: A Case Study from Banking Sector

Please indicate your answers by filling in the box like this: $\mathbf{V}$, if you make a mistake do this: $\mathbf{X}$

Sample Organization: Public Commercial Bank $\square \quad$ Private Commercial Bank $\square$

Personal Information: Sample No................. (Official)

\begin{tabular}{|c|c|}
\hline Designation: .............................. & Gross Salary: below $30,000 \square 30,000-50,000 \square$ above $50,000 \square$ \\
\hline Age: below $30 \square 30-45 \square$ above $45 \square$ & Experience: below $10 \square$ 10-20 $\square$ above $20 \square$ Sex: Male $\square$ Female $\square$ \\
\hline Marital Status: Yes $\square \quad$ No $\square$ Educa & n: SSC $\square$ HSC $\square$ Bachelor $\square$ Master $\square$ PhD $\square$ Others...... \\
\hline
\end{tabular}

\begin{tabular}{|c|c|c|c|c|c|c|c|}
\hline \multicolumn{8}{|c|}{ Survey Questions } \\
\hline \multirow{5}{*}{ 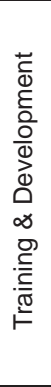 } & 1. & $\begin{array}{l}\text { I believe training increased work knowledge } \\
\text { and behavior. }\end{array}$ & $\begin{array}{c}\square \\
\text { Strongly Disagree }\end{array}$ & $\begin{array}{c}\square \\
\text { Disagree }\end{array}$ & $\begin{array}{c}\square \\
\text { Undecided }\end{array}$ & $\begin{array}{r}\square \\
\text { Agree }\end{array}$ & $\begin{array}{c}\square \\
\text { Strongly Agree }\end{array}$ \\
\hline & 2. & $\begin{array}{l}\text { Training and development ena- ble to share } \\
\text { knowledge transfer. }\end{array}$ & Strongly Disagree & $\begin{array}{l}\square \\
\text { Disagree }\end{array}$ & Undecided & $\square$ & Strongly Agree \\
\hline & 3. & $\begin{array}{l}\text { Training and development decreased work } \\
\text { place pressure. }\end{array}$ & Strongly Disagree & Disagree & Undecided & Agree & Strongly Agree \\
\hline & 4. & $\begin{array}{l}\text { Training and development link with career } \\
\text { development. }\end{array}$ & Strongly Disagree & Disagree & Undecided & Agree & Strongly Agree \\
\hline & 5. & $\begin{array}{l}\text { Training increased job satis-faction and } \\
\text { employees moral. }\end{array}$ & Strongly Disagree & Disagree & Undecided & $\begin{array}{r}\square \\
\text { Agree }\end{array}$ & Strongly Agree \\
\hline \multirow{5}{*}{ 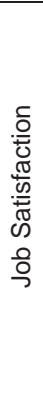 } & 6. & My job is secure. & Strongly Disagree & Disagree & Undecided & Agree & Strongly Agree \\
\hline & 7. & $\begin{array}{l}\text { Financial benefit is good compared to } \\
\text { workload. }\end{array}$ & $\begin{array}{c}\square \\
\text { Strongly Disagree }\end{array}$ & $\begin{array}{c}\square \\
\text { Disagree }\end{array}$ & $\begin{array}{c}\square \\
\text { Undecided }\end{array}$ & $\square$ & Strongly Agree \\
\hline & 8. & $\begin{array}{l}\text { I feel better as holding a prestigious/leading } \\
\text { position. }\end{array}$ & $\begin{array}{c}\square \\
\text { Strongly Disagree }\end{array}$ & $\begin{array}{c}\square \\
\text { Disagree }\end{array}$ & Undecided & $\square$ & Strongly Agree \\
\hline & 9. & My performance is measured. & $\begin{array}{c}\square \\
\text { Strongly Disagree }\end{array}$ & $\begin{array}{c}\square \\
\text { Disagree }\end{array}$ & $\begin{array}{c}\square \\
\text { Undecided }\end{array}$ & $\square$ & Strongly Agree \\
\hline & 10. & Have career prospects. & $\begin{array}{c}\square \\
\text { Strongly Disagree }\end{array}$ & $\begin{array}{c}\square \\
\text { Disagree }\end{array}$ & $\begin{array}{c}\square \\
\text { Undecided }\end{array}$ & $\begin{array}{r}\square \\
\text { Agree }\end{array}$ & Strongly Agree \\
\hline \multirow{5}{*}{ 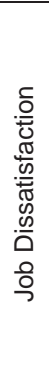 } & 11. & Work life is inflexible and tide. & $\begin{array}{c}\square \\
\text { Strongly Disagree }\end{array}$ & $\begin{array}{c}\square \\
\text { Disagree }\end{array}$ & $\begin{array}{c}\square \\
\text { Undecided }\end{array}$ & $\square$ & $\begin{array}{c}\square \\
\text { Strongly Agree }\end{array}$ \\
\hline & 12. & Inconvenient work schedule. & $\begin{array}{c}\square \\
\text { Strongly Disagree }\end{array}$ & $\begin{array}{c}\square \\
\text { Disagree }\end{array}$ & $\begin{array}{c}\square \\
\text { Undecided }\end{array}$ & $\begin{array}{r}\square \\
\text { Agree }\end{array}$ & Strongly Agree \\
\hline & 13. & $\begin{array}{l}\text { Duties and responsibilities are excessive in } \\
\text { this organization. }\end{array}$ & $\begin{array}{c}\square \\
\text { Strongly Disagree }\end{array}$ & $\begin{array}{c}\square \\
\text { Disagree }\end{array}$ & Undecided & $\square$ & $\begin{array}{c}\square \\
\text { Strongly Agree }\end{array}$ \\
\hline & 14. & Innovative ideas are not considered. & $\begin{array}{c}\square \\
\text { Strongly Disagree }\end{array}$ & Disagree & Undecided & $\square$ & Strongly Agree \\
\hline & 15. & To me, boss is unconcern often interfere. & $\begin{array}{c}\square \\
\text { Strongly Disagree }\end{array}$ & $\begin{array}{l}\square \\
\text { Disagree }\end{array}$ & Undecided & $\square$ & Strongly Agree \\
\hline \multirow{5}{*}{ 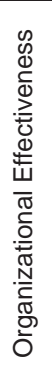 } & 16. & $\begin{array}{l}\text { Organizations do believe on continuous } \\
\text { quality improvement. }\end{array}$ & $\begin{array}{c}\square \\
\text { Strongly Disagree }\end{array}$ & Disagree & Undecided & $\begin{array}{r}\square \\
\text { Agree }\end{array}$ & Strongly Agree \\
\hline & 17. & $\begin{array}{l}\text { Consistent communication and well meaning } \\
\text { strategy. }\end{array}$ & Strongly Disagree & Disagree & Undecided & $\square$ & Strongly Agree \\
\hline & 18. & $\begin{array}{l}\text { Having need based training program to cope } \\
\text { with changing environment }\end{array}$ & Strongly Disagree & Disagree & Undecided & $\square$ & Strongly Agree \\
\hline & 19. & $\begin{array}{l}\text { Well understanding communi-cation and } \\
\text { organizational policy. }\end{array}$ & Strongly Disagree & Disagree & Undecided & $\square$ & Strongly Agree \\
\hline & 20. & Have consistency with word and action. & $\begin{array}{c}\square \\
\text { Strongly Disagree }\end{array}$ & $\begin{array}{c}\square \\
\text { Disagree }\end{array}$ & $\begin{array}{c}\square \\
\text { Undecided }\end{array}$ & $\square$ & Strongly Agree \\
\hline
\end{tabular}

This questionnaire survey is conducted for the research purpose, confidentiality will be strictly maintained. Thank you for your kind cooperation. 